\title{
ASPECTS OF MANAGEMENT ETHICS IN THE CZECH REPUBLIC
}

\author{
Radim MAŇÁK \\ Department of Entrepreneurship and Management \\ University of Entrepreneurship and Law Praha \\ Vendula FIALOVÁ \\ Department of Entrepreneurship and Management \\ University of Entrepreneurship and Law Praha
}

Received: 24. March 2020, Reviewed 02. May 2020, Accepted 16. May 2020

\begin{abstract}
This paper focuses on selected aspects of management ethics, which can be a very important factor influencing the behaviour and performance of employees. The aim of the paper is to analyze selected aspects of management ethics in the Czech business environment and to evaluate the seriousness of management ethics issues. The paper follows two main approaches: management ethics and ethical leadership. Based on the literature review, a questionnaire is used to collect data from 50 respondents who are all active in management positions. A statistical evaluation of gained results is processed and the results confronted with the theoretical background. The findings show that management ethics and ethical leadership are of big importance to managers. Managers should concentrate on such issues as bribery and communication regardless of the economic sector and number of employees in the company.
\end{abstract}

Key words: management ethics, ethical leadership, ethical values

JEL Classification: M12, M14

\section{Introduction}

Manager's work and competencies are of great importance even in the current highly mechanized and digitalized environment, and on top of that this environment brings new challenges for managers and leaders. Their role in an organization is determined by a whole set of personal and vocational characteristics. The principles of managerial ethics and their respecting seem to be a key aspect that influences the way the work of manager is carried out.

This paper accentuates the ethical aspects of managerial work and follows two key approaches: management ethics and ethical leadership. Its goal is to evaluate selected aspects of managerial ethics from the view of their importance and presence in the activities of managers and leaders in the Czech business environment. 


\section{Theoretical and research background}

The ethical integrity of a manager, mainly his ethical qualities and behavior, is essential for ethics in organization (Remišová, 2015, p. 98).

Bláha et al. (2013, p. 219) describe management ethics as ethics of management with the relation between superior and subordinate employees of a company. It provides basic normative orientation according to other people which manager comes in touch with and it serves as a guide to self-reflection, self-control and self-regulation of own behavior. As Collins $(2019$, p. 234) points out that the manager sets an example in the manner he behaves towards customers, owners, and employees within his work unit. In line with this statement Horváthová, Bláha and Čopíková (2016, p. 118) accentuate, in the context of manager's work, the importance of ethical role models for leading by example.

A line of research papers was dedicated to management ethics. Condel, Niculae, Ştefan and Popescu (2014) discussed this area of business ethics in connection with communication; Redondo, Martelo and Granados-Conde (2018) analyzed such aspects of management ethics as loyalty, honesty, discipline, responsibility, respect, equity, autonomy, effectiveness, and transparency. Weber (2017) dealt with value orientation of millennials and two managerial populations.

Other academicians research the area of ethical leadership (Frisch, Huppenbauer, 2014; Levine, Boaks, 2014; Paterson, Huang, 2018). Yang (2014) analyzed the impact of ethical leadership on employees' well-being, job satisfaction and life satisfaction. He comes to an interesting conclusion that the process of ethical leadership establishment may take its toll on the subordinates' well-being (p. 521). Zoghbi-Manrique-de-Lara and Suárez-Acosta (2014) researched the impact of ethical leadership on deviant workplace behavior and organizational citizenship behavior.

Schwartz (2017, p. 208) makes an interesting connection between management ethics and ethical leadership by distinguishing two dimensions of ethical leadership. The "moral person" dimension presents general moral obligation of one person to another where the living a moral life and doing the right thing goes hand in hand with treating people with dignity and respect, being open, actively listening, and showing concern. The "moral manager" dimension represents the manager's role within the company's ethics management system and expects him to become the rolemodel of ethical conduct communicating regularly about ethics and values and when applying the reward system, work in line with the company's standards. In the context of management ethics, firstly ethical standards and secondly ethical problems are discussed. Managers perceive the following ethical standards as the most important: reliability, professionalism, responsibility, respecting others dignity, creation of own integrity (Bláha et al, 2013, p. 220). On the other hand, these following problems were identified by Baumhart: moral issues according to recruitment and dismissals of employees, non-transparency and unfairness in communication, ambiguously set criteria of work evaluation, issue of bribes, pressure from superiors to possible unethical behavior (Rolný, 2014, p. 131-132). 


\section{Material and Methods}

The presented results of literature review show that two basic groups of elements are discussed in the context of management ethics, namely ethical standards and ethical problems. Furthermore, the moral person and moral manager as dimensions of ethical leadership are identified. In line with these premises a research concept is applied to verify them in the Czech environment.

Two basic research questions were asked: What are the key values of management ethics perceived by Czech managers? What are the key problem issues of management ethics perceived by Czech managers?

As a research tool, a questionnaire is constructed with three main areas: values of management ethics, problems of business ethics and dimensions of ethical leadership. The language of the questionnaire is Czech corresponding to the mother tongue of respondents. The respondents were asked with what role they identify (manager or leader), what level of importance they assign to adhering to ethical principles in their work, what level of importance they assign to chosen values, to evaluate the rate of seriousness of chosen problematic issues and to assess the statements regarding "moral person" dimension and "moral manager" dimension. An open question was used to determine ethical problems occurring in management work nowadays.

For the scale questions (level of importance, rate of seriousness, etc.) a fourpoint scale was used to avoid the respondents using the middle point of the scale.

The questionnaire was distributed in printed form in December 2019 among the respondents, who were part-time participants of management and entrepreneurship courses. The research was aimed at the participants in management positions.

Gained results were analyzed with help of Microsoft Excel and IBM SPSS Statistics. For the rate of importance, resp. seriousness is used a number scale from 1 (the lowest level) and 4 (the highest level). Such statistical tools as the Contingency Coefficient, Cramer`s V, Phi coefficient, Kruskal-Wallis test and Spearman Correlation coefficient were used for determining the dependencies.

Despite the lower number of respondents which may be perceived as a limitation of this research, it is greatly outweighed by its focus on respondents from the group of managers engaged in the management ethics issues in their everyday work.

\section{Results and Debate}

\section{Research sample}

50 managers took part as participants of the research. These participants work mostly in the companies of private sector (47), only 3 were from public sector. The secondary and tertiary sectors are represented equally (each 24) whereby 2 respondents stated the quaternary sector. The size of companies is distributed as follows: 17 with up to 10 employees, 6 with 11-50 employees, 15 with 51-250 employees and 12 with 251 and more employees. 


\section{Analysis of results}

Q1: What role do you hold in your position?

Firstly, the respondents were asked about the role they play in the managerial position. The most respondents (31) answered they play the role of manager and leader equally; 17 respondents consider themselves mostly as managers and only 2 of them mostly as leaders. The Contingency Coefficient, Cramer`s V and Phi coefficient show that this variable is on the $5 \%$ level of significance independent of economic sector and the number of employees. The results are presented in tables 1 and 2.

Tab. 1: Contingency Coefficient of manager/leader role and economic sector

\begin{tabular}{|l|l|l|l|}
\hline Symmetric Measures & Value & Approx. Sig. & \\
\hline Nominal by Nominal & Phi &, 380 &, 126 \\
\hline & Cramer's V &, 268 &, 126 \\
\hline & Contingency Coefficient &, 355 &, 126 \\
\hline N of Valid Cases & 50 & \\
\hline
\end{tabular}

Source: own research, IBM SPSS Statistics

Tab. 2: Contingency Coefficient of manager/leader role and number of employees

\begin{tabular}{|l|l|l|l|}
\hline Symmetric Measures & Value & Approx. Sig. & \\
\hline Nominal by Nominal & Phi &, 382 &, 294 \\
\hline & Cramer's V &, 270 &, 294 \\
\hline & Contingency Coefficient &, 357 &, 294 \\
\hline N of Valid Cases & 50 & \\
\hline
\end{tabular}

Source: own research, IBM SPSS Statistics

Q2: What level of importance do you assign to adhering to ethical principles in your work?

The importance of adherence to ethical principles in general gained the average value of 3,58. A detailed look shows that respondents with a decided understanding of their role as managers or leaders assign more importance $(3,65$, resp. 4,00$)$ than respondents with mixed role $(3,51)$. According to the number of employees the highest values are in companies with 11-50 and 51-250 employees, which means that respondents from small and big companies assign lower importance to this aspect. There was found no significant dependency on economic sector and role manager/leader (Kruskal-Wallis test) and in the number of employees (Spearman Correlation coefficient).

Q3: What level of importance do you assign to the following values? 
For the purposes of the research, it is interesting what importance respondents assign to ethics values. The importance is measured on scale from 4 (the highest level) to 1 (the lowest level). The results are shown in figure 1 .

Fig. 1: Importance of values

Importance of values

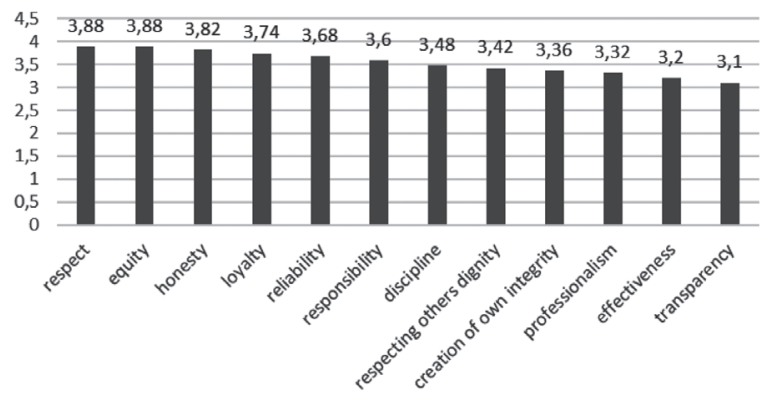

Source: own research

The 3 values with the highest level of importance are respect $(3,88)$, equity $(3,88)$ and honesty $(3,82)$. On the other side of the list are professionalism $(3,32)$, effectiveness $(3,2)$ and transparency $(3,1)$.

The levels of importance of only two values are directly dependent on the number of employees: respect and creation of own integrity with the Spearman Correlation coefficient values of 0,343 , resp. 0,309 . Similarly, the importance of values is mostly independent of role manager/leader or economic sector. Respect, equity and reliability are statistically dependent on the role of respondents and effectiveness; responsibility and reliability in the economic sector in all cases according to the KruskalWallis test.

The dependency analysis shows that the importance of ethical values and adhering to them does not derive from economic sector, number of employees or even from the role played by respondents at workplace. It is probably rooted deeper in value orientation of individuals.

Q4: Evaluate the rate of seriousness of the following issues.

In the next part of the questionnaire, the seriousness of issues connected to management ethics is evaluated. Basic results are presented in figure 2. 
Fig. 2: Seriousness of issues

\section{Seriousness of issues}

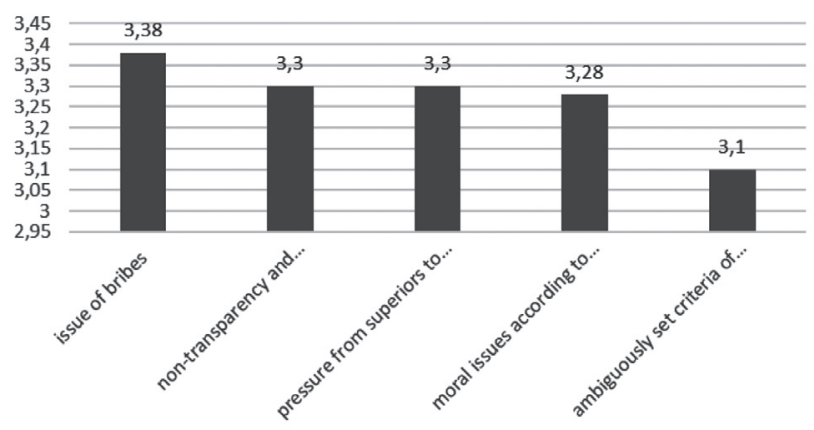

Source: own research

The study shows that bribery is perceived as the most problematic issue with the average value of 3,38 . On the other side of the scale lies ambiguously set criteria of work evaluation with value of 3,1.

The analyzed issues are all independent of economic sector, only two of them (non-transparency and unfairness in communication, issue of bribes) show statistically significant dependency on the role manager/leader, based on the Kruskal-Wallis test.

It has been proved that with the higher number of employees, nontransparency and unfairness in communication is found more serious by the respondents. The Spearman Correlation coefficient shows the value of 0,395, which means a direct and middle strong correlation. These findings could be connected with the fact that communication in bigger companies is more complicated and structured.

From the viewpoint of human resources management, it is quite interesting that the pressure from superiors to possible unethical behavior correlates directly and middle strongly with moral issues according to recruitment and dismissal of employees with the value of Pearson Correlation coefficient 0,542.

Q5: Assess the rate the following statements correspond with your approach to work.

The respondents were asked about their agreement with statements concerning ethical aspects of private and vocational life. In figure 3 are presented basic results.

It can be seen that respondents mostly agreed to the statement treating people with dignity and respect $(3,74)$. The lowest level of agreement is found by communicating openly and regularly about ethics and values $(2,98)$.

In most cases, no significant dependencies between statements and identification questions were found. Only the statement "Treating people with dignity and respect" shows statistically significant dependence on role manager/leader. It proves again that the number of employees or economic sector are not a significant factor in management ethics, the moral qualities of individuals would probably have a greater impact. 
Fig. 3: Statements about ethical aspects

\section{Statements about ethical aspects of life and work}

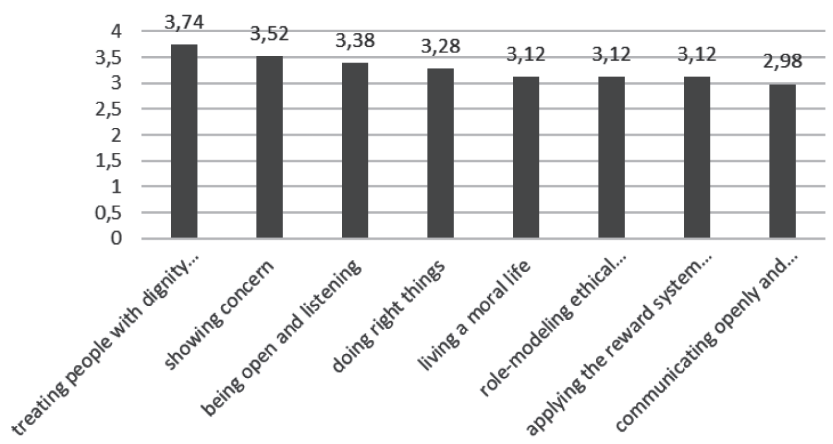

Source: own research

In line with Schwartz (2017,) these statements can be assigned to "moral person" dimension and "moral manager" dimension. It is interesting that statements about "moral person" dimension achieved higher average value of 3,41 compared to statements about "moral manager" dimension with 3,07. This result can mean that the respondents' activities correspond more with the role of leader than of manager. This is in strong contrast with the self-evaluation of their role where respondents consider themselves more as managers than leaders. It is interesting that the correlation matrix shows no strong dependencies, even in the groups of statements assigned to individual dimensions.

Q6: What most important ethical problems occur in management work nowadays?

In order to gain more information a questionnaire was completed with an open question about the most important ethical problems in their work. This opportunity was used by 20 respondents. The responses are presented in the table 3 .

Tab. 3: Ethical problems of management work

\begin{tabular}{|l|}
\hline lie \\
\hline employees do not want to take responsibility for their actions \\
\hline disloyalty, distrust, ignorance \\
\hline $\begin{array}{l}\text { handling personal data, engagement of employees as if they were working in their own company, } \\
\text { engagement }\end{array}$ \\
\hline $\begin{array}{l}\text { the requirement of subordinate to work beyond their duties, breach of loyalty in the company } \\
\text { by subordinates }\end{array}$ \\
\hline the private needs of subordinates are not taken into account, focusing on results at all costs \\
\hline low transparency, unclear strategy given the market situation \\
\hline $\begin{array}{l}\text { inequality of remuneration, insufficient communication of top management with employees on } \\
\text { an operational level }\end{array}$
\end{tabular}




\begin{tabular}{|l|}
\hline access to company property, racially insensitive statements in the working team \\
\hline non-transparent granting of benefits \\
\hline Identification with the company and its values \\
\hline insincerity, irresponsibility \\
\hline prioritizing profit over social responsibility \\
\hline communication \\
\hline lying \\
\hline irresponsibility for decisions \\
\hline distrust \\
\hline disloyalty \\
\hline focus only on performance \\
\hline unequal pay \\
Source: own research
\end{tabular}

The respondents mentioned mostly management failures such as inequality in remuneration or only performance focus. Other often mentioned problems relate to communication including lying, non-transparency, lack of loyalty and identification with the company.

\section{Conclusion}

The paper dealt with selected aspects of management ethics. The results can help to understand, what practicing managers consider as values and activities of management ethics.

The most important values for the interviewed managers are respect, equity, honesty and loyalty. The most serious issues are felt to be bribes, non-transparency and unfairness in communication. The second mentioned was confirmed in the answers for the open question. The respondents identify themselves mainly with activities such as treating people with dignity and respect or showing concern.

The results of Redondo, Martelo and Granados-Conde (2018) were partially confirmed while their research assigned the highest average rate to the values respect and honesty. On the other hand, while highly rated in this research, equity was classified lower in their findings.

As the results show, the analyzed aspects of management ethics are in most cases independent of economic sector, the number of employees or even the perceived role of respondents. These aspects could be more affected by value orientation of the respondents.

Based on the achieved results, it would be appropriate to focus on further research into the dependence of the importance of ethical values and value orientation of an individual on selected factors. 


\section{Bibliography}

1. Bláha, J. et al. (2013). Pokročilé řízení lidských zdrojů. Brno: Edika. ISBN 978-80266-0374-0.

2. Collins, D. (2019). Business Ethics. Best Practices for Designing and Managing Ethical Organizations. Los Angeles: Sage. ISBN 978-1-5063-8805-2.

3. Condel, R., Niculae, I., Ştefan, P., \& Popescu, A. (2014). Ethics and Communication in Management. Scientific Papers Series Management, Economic Engineering in Agriculture and Rural Development, 14(3), 47-54. http://managementjournal. usamv.ro/pdf/vol_14/art7.pdf

4. Frisch, C., \& Huppenbauer, M. (2014). New Insights into Ethical Leadership: A Qualitative Investigation of the Experiences of Executive Ethical Leaders. Journal of Business Ethics, 123(1), 23-43. https://link.springer.com/article/10.1007/ s10551-013-1797-9.

5. Horváthová, P., Bláha, J., \& Čopíková, A. (2016). Řízení lidských zdrojů: nové trendy. Praha: Management Press. ISBN 978-80-7261-430-1.

6. Levine, M. P., \& Boaks, J. (2014). What Does Ethics Have to do with Leadership? Journal of Business Ethics, 124(2), 225-242. https://link.springer.com/ article/10.1007/s10551-013-1807-y

7. Paterson, T. A., \& Huang, L. (2018). Am I Expected to Be Ethical? A RoleDefinition Perspective of Ethical Leadership and Unethical Behavior. Journal of Management, 45(7), 2837-2860. https://journals.sagepub.com/doi/abs/10.1177/ 0149206318771166

8. Redondo, C. M., Martelo, R. J., \& Granados-Conde, C. (2018). Managerial Ethics and Workplace Harassment in the Public Sector. Contemporary Engineering Sciences, 11(39), 1911-1919. http://www.m-hikari.com/ces/ces2018/ces37-402018/p/marteloCES37-40-2018-2.pdf

9. Remišová, A. (2015). Súčasné trendy podnikatel'skej etiky: od teórie k praxi. Bratislava: Wolters Kluwer. ISBN 978-80-8168-213-1.

10. Rolný, I. (2014). Budujeme do̊věryhodnou firmu. Praha: C.H. Beck. ISBN 978-807400-286-1.

11. Schwartz, Mark S. (2017). Business ethics: an ethical decision-making approach. Chichester: Wiley Blackwell. ISBN 978-1-118-39343-7.

12. Weber, J. (2017). Discovering the Millennials' Personal Value Orientation: A Comparison to Two Managerial Populations. Journal of Business Ethics, 143(3), 517-529. https://link.springer.com/article/10.1007/s10551-015-2803-1

13. Yang, C. (2014). Does Ethical Leadership Lead to Happy Workers? A Study on the Impact of Ethical Leadership, Subjective Well-Being, and Life Happiness in the Chinese Culture. Journal of Business Ethics, 123(3), 513-525. https://link. springer.com/article/10.1007/s10551-013-1852-6

14. Zoghbi-Manrique-de-Lara, P., \& Suárez-Acosta, M. A. (2014). Employees' Reactions to Peers' Unfair Treatment by Supervisors: The Role of Ethical Leadership. Journal of Business Ethics, 122(4), 537-549. https://link.springer.com/article/10.1007/ s10551-013-1778-z 


\section{Correspondence address:}

PhDr. Ing. Radim Maňák, Ph.D., Department of Entrepreneurship and Management, University of Entrepreneurship and Law, Vltavská 585/14, 15000 Praha 5, email: radim. manak@vspp.cz

Ing. Vendula Fialová, Ph.D., Department of Entrepreneurship and Management, University of Entrepreneurship and Law, Vltavská 585/14, 15000 Praha 5, vendula. fialova@vspp.cz 